\title{
Conceptualization of CSR Among Muslim Consumers in Dubai: Evolving from Philanthropy to Ethical and Economic Orientations
}

\author{
Valerie Priscilla Goby $\cdot$ Catherine Nickerson
}

Received: 12 September 2014/ Accepted: 15 December 2014/Published online: 21 December 2014

(C) The Author(s) 2014. This article is published with open access at Springerlink.com

\begin{abstract}
Many existing studies postulate that in developing economies philanthropy tends to dominate in the CSR orientation delivered by organizations and expected by local populations. To assess this in the emerging economy of Dubai in the United Arab Emirates, we conducted a preliminary investigation of how locals are responding to the growing number of CSR initiatives that are being implemented in the Emirate. Moreover, given that scholars have argued that Islamic principles of philanthropy should guide CSR initiatives in Muslim countries, we also consider if our Emirati respondents connect CSR with Islamic philanthropy. Results from our survey of 267 local Muslim consumers in Dubai indicate that CSR is not typically equated with philanthropy. In addition, respondents displayed an appreciation of the economic benefits that CSR can generate. The implication is that organizations in Dubai no longer need to base their CSR on the platform of Islamic philanthropy as many scholars have argued. Our findings are significant for the wider Gulf region in that they suggest that in wealthy emerging nations, CSR may not be predominantly interpreted as the corporate philanthropy which is needed in poorer developing economies for the provision of infrastructure, schools, hospitals, and housing, and which in some Muslim contexts is also implemented because of local religious values.
\end{abstract}

Keywords CSR $\cdot$ Philanthropy $\cdot$ Islam $\cdot$ Dubai $\cdot$ Middle East $\cdot$ Religion $\cdot$ Zakat

\footnotetext{
V. P. Goby $(\bowtie) \cdot$ C. Nickerson

College of Business, Zayed University, P. O. Box 19282,

Dubai, United Arab Emirates

e-mail: ValeriePriscilla.Goby@zu.ac.ae

C. Nickerson

e-mail: catherine.nickerson@zu.ac.ae
}

\section{Introduction}

Recent years have witnessed much investigation of the understanding and implementation of corporate social responsibility (CSR) beyond Western contexts (e.g., Arevalo and Aravind 2011; Ramasamy and Ting 2004; Ringov and Zollo 2007; Robertson 2009). Scholars have begun to test the validity of CSR models in many emerging economies and variations have been widely reported in the way in which CSR is perceived in different cultural and economic contexts (Muthuri et al. 2009; Jamali et al. 2009a; Planken et al. 2013). A significant distinction in the research on CSR is that between philanthropic CSR, the donating of money or other resources for the improvement of community welfare, and ethical CSR, which is concerned more with corporate decision-making based on laudable, recognizable, sociallyconscious values (Carroll 1979). Practicing one type of CSR more than another is termed the Corporate Social Responsibility Orientation (CSRO) that corporations maintain. Carroll (1979) identifies four sets of priorities that corporations fulfill in a set order when constructing their CSR policies. These are: (i) economic concerns which imply that corporations must first and foremost be profitable; (ii) legal concerns which imply that corporations must abide by the law; (iii) ethical concerns which imply that they must behave in s socially acceptable way; and (iv) philanthropic concerns which imply that they can engage in charitable giving. He postulates, for instance, that once corporations in Western contexts have taken care of their economic and legal responsibilities, they then privilege ethical CSR and focus on being a good corporate citizen with little or no emphasis given to philanthropic concerns. In contrast, Visser's (2007) study of CSR in developing countries maintains that corporations first take care of their economic responsibilities, but that they then focus their CSR efforts on philanthropy 
with less emphasis on either legal or ethical concerns. Recent studies of CSRO in emerging economies, however, have revealed findings contradicting Visser's (2007) assertion, and more investigation is needed of how corporations in the developing world construct their CSR initiatives as well as of how these initiatives are perceived by local populations.

In the Middle East in particular, studies of CSR and CSRO remain in their infancy, although the 2012 collection edited by Jamali and Sidani (2012) is a clear indication of the scholarly interest in the region. Recent studies include Jamali's (2010) study of CSR orientations in MNCs in Lebanon, Jamali et al.'s (2009a) comparison of managerial CSR perspectives in Lebanon, Syria, and Jordan, and Turker's (2009a) survey of business professionals about CSR and their commitment to the organization in Turkey. Despite this interest, however, the majority of studies that examine CSR and CSRO thus far in developing countries have been conducted outside of the Arabian Gulf region, notably in Africa (e.g., Lindgreen et al. 2009), South America (e.g., Yakovleva and Vazquez-Brust 2012), and Asia (e.g., Tian et al. 2011). In addition, with the exception of the exploratory study of CSR by Katsioloudes and Brodtkorb (2007) and the large-scale study by Rettab et al. (2009) which investigated stakeholder perceptions of CSR in Dubai, little is known about CSR in the United Arab Emirates (UAE) and the wider Gulf Region. Similarly, while there have been a number of recent studies that have investigated the influence of Islam as the predominant religion in the region, on various aspects of the corporate world (e.g., Uygur 2009, on work ethics; Saeed et al. 2001, on marketing ethics; Rice 2006, on environmental ethics), there have, as yet, been very few studies that have looked at the relationship between Islam and CSR orientation. One exception is the study by Williams and Zinkin (2010) that establishes a convergence between Islam and the principles of responsible business practice outlined by the UN Global Compact as a proposed set of standards for CSR across the globe (http://www.unglobalcompact.org/).

Finally, the business case for identifying suitable CSR platforms for Muslim markets is compelling since Muslims represent approximately a quarter of the world's population, or 1.6 billion, and their spending power is on the increase. In the USA alone, Muslim spending power is cited as $\$ 170$ billion (Hastings-Black 2011), and, in the Arabian Gulf, the GDPs of countries such as Qatar, Kuwait, and the UAE are among the highest in the world (World Economic Outlook Database-September 2011). The economic possibilities afforded by the rise in Muslim spending power have led to research on issues related to Islamic values in business. For example, Rice and AlMossawi (2002) examine the targeting of Muslim groups by profit-making organizations, Oumlil and Balloun (2009) contrast how religion influences the ethical decision-making of American versus Moroccan managers, and Schneider et al. (2011) investigate the possible influence of religious belief on consumer behavior among Christian consumers in Germany and Muslim consumers in Turkey. Given the notable increase in Muslim spending power, most especially in the Arabian Gulf, and the large numbers of MNCs now vested in the region, further investigation of stakeholder expectations and preferred CSRO is both necessary and timely. Our study aims to contribute to this research stream.

\section{Focus of Current Study}

Our study's purpose is twofold. First, we wanted to find out what Emirati citizens know about CSR and CSR initiatives in the emerging economy of Dubai in the UAE and furthermore, if they did know about CSR in Dubai, whether they would also show an awareness of different CSR orientations, including the connection between the economic concerns related to a corporation's profits, and CSR initiatives in general. Scholars such as Rettab et al. (2009) and Katsioloudes and Brodtkorb (2007), for instance, contend that CSR is now a viable corporate strategy in Dubai that is likely to impact both financial performance and corporate reputation in a positive way, while Visser (2007) argues that a philanthropic CSR orientation is likely to be highly significant in developing nations and perceived in a positive light. On CSR in general and on the communication of CSR in particular, Bhattacharya and Sen (2004) and Du et al. (2010) argue that an awareness of a corporation's CSR initiatives and the causes with which it is associated are important internal outcomes for stakeholders such as consumers and employees. Once developed, awareness then directly influences stakeholder behavior and the possibility that this will result in certain important external outcomes including employee and consumer loyalty to a corporation. In addition, Sen et al. (2006) provide empirical support for the link between an awareness of CSR and whether or not a stakeholder will invest in, purchase from, or seek employment with, a particular organization (Sen et al. 2006). Finding out what our respondents knew about CSR in general, and CSR orientations in particular was therefore necessary in determining whether CSR and philanthropic CSR would be likely to influence the Dubaibased Emirati population in a positive way.

Second, we also wanted to assess how the local religion impacts the understanding of what CSR is, or should be, by the Emirati community. Lindgreen et al. (2010, p. 229) stress that "cultural aspects often determine what is required and expected of organizations with regard to economic, legal, ethical, and discretionary concerns," and we therefore attempt to identify how cultural issues related to Islam 
influence the population's understanding and expectations of CSR. In order to do this, we look specifically at the issue of charity or zakat, which is a religious concept, prescribed in Islam, and which is akin to what Quazi and O'Brien (2000) consider to be the philanthropic view of CSR.

This study will first review the existing literature on CSR orientation, the impact of religion on CSR, CSR in Dubai, and Islamic philanthropy. We then present the methodology that we use and we report and discuss our survey of 267 local Muslim consumers. The survey investigated respondents' familiarity with, and understanding of, the term CSR, their belief in the capacity of CSR to contribute to economic development, their knowledge of CSR initiatives in Dubai, and what they perceived to be the relationship between CSR and zakat. Finally, we summarize the implications of our findings for corporations operating in the Middle East, identify the limitations in our study, and make some suggestions for future research.

\section{Literature Review and Theoretical Background to the Study}

\section{CSR Orientation}

As we outline in our "Introduction," the Four Step Pyramid of CSR proposed by Carroll $(1979,1991)$ suggests that CSR initiatives prioritize one or more of four sets of factors, or orientations, relating to the economic, legal, ethical, and philanthropic obligations a corporation has toward society in general and its stakeholders in particular. This work has been extremely influential in the 30-year period since it was first put forward, and numerous scholars have investigated CSR orientations and stakeholder response to those orientations in a wide variety of contexts in the developed world. Their findings suggest both similarities and differences with Carroll's assertions regarding the presence of and priority assigned to a given orientation, driven by both industry sector and geographical location (e.g., Esrock and Leichty 1998, on sector; Maignan and Ralston 2002, on location; Podnar and Golob 2007, on stakeholder response).

Visser (2007) proposes an equally influential adaptation of Carroll's model to account for CSR orientations in the developing world given the very different social and economic context that corporations in emerging economies need to deal with. He suggests a re-ordering of priorities such that although economic obligations and the requirement to be profitable remain in first place, philanthropic obligations follow in second place, and lastly legal and ethical obligations. Once again, numerous scholars have investigated Visser's contentions in various emerging economies around the world and have revealed a complex situation where the priorities set for a particular CSR orientation, as well as the stakeholder's perceptions of that orientation, may be related to a variety of different factors that go beyond just the geographical location of the corporate entity under investigation. For instance, the studies by Arora and Puranik (2004), Sagar and Singla (2004), Chapple and Moon (2005), and Muruganantham (2010) all report on a philanthropic orientation as a major concern for corporations in India. In contrast, however, Planken et al. (2013) found that Indian stakeholders considered this to be their least preferred type of CSR initiative because of the possible association that there could be with corruption (see also Sundaresan 2010). Likewise, Lindgreen et al. (2009) found no evidence for a divergence from Carroll's original prioritization of CSR orientations in their investigation of corporations in Botswana and Malawi, but they did find differences in how CSR policy was implemented in both countries depending on the structure of the organization. Finally, Yakovleva and Vazquez-Brust (2012) identify five categories of CSR reported by the mining MNCs that they investigated in Argentina (economic, ethical, environmental, legal, philanthropic) with philanthropic concerns falling in fifth and last place. They also report that the emphasis placed on each one was dependent on the corporate entity involved and the industrial sector, and not on the fact that the MNC was operating in an emerging economy; for example, ethical responsibilities are defined by headquarters, whereas environmental responsibilities are dealt with locally.

\section{CSR Orientation in the Middle East}

As mentioned above, not much is known about CSR and CSR orientations in the Middle East, either in terms of what corporations do, or of stakeholders' perceptions and expectations. The few studies that have been conducted, however, indicate that the region may be fertile ground for scholars with an interest in how CSR is operationalized in the rapidly emerging economies it represents. Jamali (2010), for instance, reveals a combination of global and local CSR practices in the MNCs she investigated in Lebanon, and Jamali et al. (2009a) report on both similarities and differences in managerial perspectives on CSR in Lebanon, Syria, and Jordan. Jamali et al. (2009b) found that managers of SMEs in Lebanon equated CSR with an obligation to support philanthropy, whereas MNC managers there were more likely to associate CSR with an ethical orientation combined with a discretionary orientation involving optional philanthropic contributions. Elsewhere in the region, Turker $(2009 \mathrm{a}, \mathrm{b})$ investigates the responsibilities of corporations to different groups of stakeholders in Turkey and the impact these responsibilities have upon them, illustrating that a fine-grained approach is necessary to capture the diversity that exists between the different stakeholder groups. Finally, Rettab et al. (2009) show that there is a direct link between CSR activity and the financial 
performance of Dubai-based corporations, as well as a direct link between CSR activity and both corporate reputation and employee commitment. What these studies indicate is that the choice of a particular CSR orientation may be determined by local values and expectations in the Middle East region, and, equally, that these same values and expectations may then affect how corporations are viewed by their stakeholders.

\section{Religion and CSR}

Various aspects of the relationship between religion and CSR have been noted in the literature. For example, Vitell et al. (2005, 2006) investigate religiosity and consumer ethics; Jamali and Sidani (2013) look at religiosity and CSR orientation; Ramasamy et al. (2010) trace the relationship between religiosity, values, and support for CSR; Kennedy and Lawton (1998) explore the link between religiousness and business ethics; and Graafland et al. (2006a) look at religious belief and executives' perceptions of business dilemmas. Specific groups of stakeholders have also been studied with, for example, research conducted on the impact of managers' religion on their practice of CSR (e.g., Arslan 2001) as well as on how religion and religiosity influence consumer behavior (e.g., Cornwell et al. 2005, Swimberghe et al. 2011). Of particular relevance for the present study is the large-scale study by Brammer et al. (2007) which draws on data gathered from 17,000 people in 20 different countries to investigate the attitudes to CSR displayed by adherents of different religions. It shows that while, in general, there was little difference between individuals who practiced different religions in their attitudes to different CSR initiatives, Muslims in particular felt that corporations should be concerned with charitable activities. Similarly, the survey of Muslim entrepreneurs in the Netherlands, conducted by Graafland et al. (2006b), shows a difference in emphasis between Muslim business people and their non-Muslim counterparts in various aspects of socially responsible business practice, including the belief that special attention should be given to dealing with customers, looking after employees, and supporting local community projects. These studies suggest that, in some cases, the religion adhered to by a local culture will influence how communities understand and evaluate different CSR initiatives, and consequently, that in order to be effective, organizations need to take religious beliefs into account in developing their CSR activities. Our study looks at a specific aspect of Islam, namely, the religious precept related to charitable giving called zakat, as it seems plausible that Muslim consumers will make a connection between zakat as required philanthropy on the part of corporations, as we discuss below, and a philanthropic orientation in CSR.

\section{CSR and Religion in Dubai}

The religion of Dubai is Islam and this incorporates an active requirement to give alms. In Islam this is termed zakat, the Arabic word for purity referring to the purity of heart that is gained from giving charity to the poor. As one of the Five Pillars of Islam, it has remained a cardinal feature of prescribed Islamic behavior since being instituted by the Prophet Mohammed. Typically it operates as the voluntary donation of money to poorer sections of one's community, as is the case in the UAE. In a few countries, most notably Saudi Arabia, Malaysia, and Pakistan, the state imposes an obligatory contribution of money for redistribution to social causes (Marty and Appleby 1993). As Rice (1999) has observed, zakat is an important element within the Islamic concept of justice (adalah) which implies caring for all members of society, and, as such, zakat has clear implications for business practice. For example, a precept relating to income redistribution is that "wealth should be shared with those less fortunate" (Rice 1999, p. 351). Most recently, Majaj and Kassis (2012) have argued that the enduring presence of zakat as an important Islamic concept is also likely to facilitate the related practice of CSR in the region. It is possible that zakat may influence how Muslims understand the concept of CSR, specifically that they are most likely to associate CSR with the type of activities such as the corporate giving that Carroll (1991) defines as philanthropic CSR, and we explore this possible link in our investigation. Previous studies on CSR in Dubai have indicated that while the implementation of CSR initiatives has a positive impact on financial performance, employee commitment, and corporate reputation (Rettab, et al. 2009), many managers in the UAE appear to be unaware of what CSR policies should be and how they should be implemented (Katsioloudes and Brodtkorb 2007). Moreover, research indicates low levels of awareness of the concept and practice of CSR within the local community in Dubai (Goby and Nickerson 2012). As we have outlined above, since an awareness of a corporation's CSR initiatives is an important determinant in how stakeholder groups behave, and recent studies would indicate that both managers in the UAE and the general public exhibit limited knowledge, our study seeks to investigate this further with particular reference to a set of specific demographic factors (gender, age, educational level, and nature of employment).

\section{Methodology}

Research Aims

This study was undertaken to investigate how familiar our Emirati population sample was with the general term CSR 
(q. 1), its meaning (q. 2), its perceived efficacy as an economic driver (q. 3), its nature, that is, whether it is similar to Islamic zakat or not (q. 4), and its implementation by specific organizations operating in the UAE (q. 5). That is, we investigated five inter-related constructs focusing on degrees of what Block (1995) terms awareness or consciousness of the concept and practice of CSR within their local community, the perceived validity of CSR to contribute to the UAE economy, that is, a perceived economic CSRO, and the possible association of CSR with a religious imperative relating to philanthropy, that is, a proscribed philanthropic CSRO. This link with religion was prompted by assertions in the literature that CSR in the UAE is practiced in line with Islamic philanthropy as mentioned above. We also included demographic questions to allow us to relate familiarity with CSR with different demographic parameters.

\section{Survey Instrument}

We knew from previous research attempts in Middle Eastern contexts that our choice of a viable research instrument capable of yielding authentic responses was limited due to the strong tendency toward social desirability characteristic of Middle Eastern cultures (Goby 2009). This derives from the cultural imperative to maintain smooth, cordial relations, and an aversion to revealing personal matters (Zakaria et al. 2003). We chose not to use an impersonal instrument such as an online questionnaire since the UAE culture is one in which face-to-face interactions are valued over other interactive modes and which are therefore more likely to achieve respondent engagement (Zakaria et al. 2003). We opted to design a questionnaire that would serve as the prompt for short interviews. To eliminate response bias caused by fatigue or boredom (Schmitt and Stutts 1985), we confined our survey items to the following five topic-based questions, presented here together with each relevant variable in parenthesis at the end of each question:

(1) Have you heard of the term corporate social responsibility (CSR)? (familiarity with the term)

(2) Do you know what CSR means? Please give a definition of CSR (understanding of the term)

(3) Do you think that CSR can contribute to the UAE economy? If so, how? (belief in the validity of CSR as an economic driver and perceived economic CSRO)

(4) Do you believe there is a relationship between zakat and CSR? If so, please explain (respondents' understanding of the relationship, if any, between CSR and Islam-inspired philanthropy and perceived philanthropic CSRO)
(5) Please name any organizations/companies that you know of that are engaged in CSR in the UAE (practical knowledge of how specific UAE organizations implement CSR)

A final, sixth, question asked for respondents' demographic characteristics of gender, age, educational level, and nature of employment. This was included to allow us to identify personal factors within contemporary Emirati society in Dubai that influence knowledge about CSR and how the respondents conceptualize it.

The questionnaire was developed in a bilingual form. It was compiled by the authors in English, the common language of business and tertiary education in Dubai, and translated into Arabic, the first language of the local community. The translation was tested for reliability by bilingual native Arabic speakers of English using the translation/back-translation method advocated by Brislin (1980) and extensive discussion took place in order to verify the translation of the crucial concepts of zakat and CSR which were targeted in the survey. Zakat, a term that is commonly used when speaking English, was included in its Anglicized form in the English version of the questionnaire. The English acronym CSR was retained in the Arabic version of the questionnaire as there is no equivalent acronym in Arabic in use in the UAE, alongside the Arabic translation for corporate social responsibility ( $A l$ Masuolia Al Mojtamaeia Lil Sharekat) which was included in parenthesis immediately afterwards. This is a literal translation of the three English words, corporate, social, and responsibility, which is the expression used in contemporary Arabic in the UAE.

\section{Data Collection}

Those administering the survey were all bilingual Emirati nationals and both Arabic and English were used in interviewing respondents. We chose only Emirati nationals to encourage respondent engagement as research has highlighted that Emiratis show a strong preference for interacting with their co-nationals (Goby 2009). All were female because our research institute could provide no local male research assistants. We asked administrators to interview people they knew personally since in Middle Eastern cultures people prefer to conduct interactions with people whom they know and with whom they have a relationship of trust (Weiss 1998; St. Amant 2002). Given the relationship between interviewer and respondent, we needed to consider the issue of social desirability bias. However, since the survey did not focus on sensitive topics, we believed there was little risk of this. That is, the focus was on respondents' familiarity with CSR and its possible link with Islamic tenets; it did not touch on 
respondents' religiosity. Despite using only female administrators who interviewed individuals they knew personally, we considered that, given our context, it was a suitable approach that would yield authentic, valid findings. Through this method a convenience sample of 267 respondents was achieved. One hundred and forty-four of our sample responded to the English version of the questionnaire and 123 to the Arabic version.

\section{Population Sample}

The sample that emerged from our Emirati-only respondent group and employment of only female administrators was, as anticipated, skewed across some parameters. The fact that all our interviewers were female would account for the higher proportion of female respondents (192) given the cultural proscription of interactions between unrelated males and females. In terms of age, we had 178 respondents in the 20 to 30 group, 63 in the 31-45 group, and 19 in the $46+$ group. However, this imbalance reflects the youthful population of Dubai that is composed of $29.72 \%$ in the 20-30 age group and only $11.48 \%$ in the age group of 45 and above (Dubai Statistics Centre 2011). Similarly in terms of occupation, we had 126 students, 58 government workers, 41 not working, and 31 private sector workers. Again this reflects demographic realities of Dubai where more than $50 \%$ of the local population aged between 20 and 30 is in higher education (Statistical Yearbook 2010). Most working Emiratis are employed in the public sector workforce where they make up $26 \%$, while only $0.5 \%$ of the private sector workforce is Emirati (Salem and Dajani 2013).

As a multinational hub, with an estimated 220 different national cultures and diverse religious groups working side by side, Dubai has a unique profile that is not shared across the other Emirates, with the possible exception of $\mathrm{Abu}$ Dhabi (Epps and Demangeot 2013; Nickerson and Crawford-Camiciottoli 2013). Our discussion below therefore reflects the opinions of the Emirati community based only in Dubai and not those across the UAE.

\section{Results and Discussion}

We processed responses (using IBM's SPSS Version 20) and we now present and discuss our findings.

\section{Respondents' Familiarity with CSR}

The first question in our survey was whether respondents had heard of the term CSR; $35 \%$ stated that they had and $65 \%$ stated they had not. Of these respondents, $70.9 \%$ were able to provide a reasonable explanation of the term.
Question five probed respondents' knowledge of organizations involved in CSR in the UAE and of specific CSR initiatives and only $19.5 \%$ provided examples. They cited a range of different types of organizations, including private companies, government institutions, and banks.

When we looked in more detail at the demographic profile of respondents who said they had heard of the term CSR (question 1), the analysis yielded a set of interesting findings which we now discuss in terms of demographic factors and levels of awareness of CSR.

\section{Language of Response}

To establish if the language in which the questionnaire was completed was relevant to whether respondents had heard of the term CSR, we correlated the language of response with the answers to the first question (Table 1).

The $\alpha$ of .867 , higher than the $p$ value of .05, indicates no correlation between the version of the questionnaire used and yes/no responses suggesting that the language preferred by individual respondents had no relevance to their basic familiarity with the term. This was interesting as it had seemed plausible that a tendency toward English might suggest more exposure to Western culture and therefore more experience of the term. However, our findings indicate that there was no such correlation, a reflection perhaps of the widespread use of English as a lingua franca in Dubai and its neutral, rather than culturebound, status (Randall and Samimi 2010).

\section{Gender and Age}

Many researchers have explored the role of gender in relation to CSR. Robertson and Ross (2003), for example, found that females are more sensitive to CSR activities than males, while Dalton and Ortegren's (2011) study suggests that the greater value attached to CSR by females is the result of response bias and the attempt at social

Table 1 Correlation between familiarity with term and language of response

\begin{tabular}{lcc}
\hline & $\begin{array}{l}\text { Awareness } \\
\text { of CSR }\end{array}$ & $\begin{array}{l}\text { Responses in English } \\
\text { and Arabic }\end{array}$ \\
\hline $\begin{array}{l}\text { Have you heard of the term corporate social responsibility? } \\
\text { Pearson correlation }\end{array}$ & 1 & .010 \\
Sig. (2-tailed) & .867 \\
$N$ & 266 & 266 \\
Responses in English and Arabic & \\
Pearson correlation & .010 & 1 \\
Sig. (2-tailed) & .867 & \\
$N$ & 266 & 267 \\
\hline
\end{tabular}


Table 2 Gender and familiarity with term

\begin{tabular}{lcccc}
\hline & $N$ & Mean & Std. deviation & Std. error mean \\
\hline \multicolumn{4}{l}{ Have you heard of the term corporate social responsibility? } \\
Male & 70 & 1.63 & .487 & .058 \\
Female & 192 & 1.66 & .476 & .034 \\
\hline
\end{tabular}

desirability. Given the potential significance of gender in relation to CSR, we tested for familiarity as indicated by responses to the first question and gender (Table 2).

We used Levene's test to assess the equality of variance between female and male respondents and, finding $\alpha$ to be substantially higher than .05 , could identify no significant difference as shown in Table 3.

No significant difference among the age groups was detected in reported familiarity with the term CSR as indicated in Table 4.

\section{Educational Level}

One would expect that level of education would have an impact on familiarity with CSR since it seems plausible that more long-term education would impact positively, and, indeed, we found this to be the case among our respondents. Table 5 indicates that while there is little difference in familiarity with the term CSR between respondents with primary and secondary level education, there are significant differences between these groups and the university-educated group.

This difference can be attributed to two facts. First, individuals with tertiary education tend to hold higher level employment positions and are more likely to be involved in CSR initiatives within their organizations. Second, many third-level institutions in the UAE are actively involved in social awareness campaigns making students more cognizant of the broad concept of social and environmental amelioration, again in a similar way to Western institutions. For example, one of the largest government universities in the UAE, Zayed University with campuses in the two major cities of Dubai and Abu Dhabi, is committed to building a culture of volunteerism in the country and attempts to involve undergraduate students in activities
Table 4 Familiarity with term correlated with age

\begin{tabular}{lll}
\hline Tukey HSD & a,b & \\
\hline Age groups & $N$ & $\begin{array}{l}\text { Subset for } \alpha=0.05 \\
1\end{array}$ \\
\hline $20-30$ & 177 & 1.63 \\
$31-45$ & 63 & 1.67 \\
$46+$ & 19 & 1.74 \\
Sig. & & .560
\end{tabular}

Means for groups in homogeneous subsets are displayed

${ }^{\text {a }}$ Uses harmonic mean sample size $=40.456$

b The group sizes are unequal. The harmonic mean of the group sizes is used. Type I error levels are not guaranteed

relating to public health, environmental matters, literacy, women and children's issues, general awareness campaigns, and other outreach areas that enrich society (http:// www.zu.ac.ae/main/en/_ice/comm_serv1.aspx).

\section{Employment Status}

A significant difference emerged between the working and non-working respondents. Tables 6 and 7 illustrate that far more respondents in the workforce reported being familiar with the term than those not in employment.

This is perhaps a crucial indication that in Dubai, people are more effectively exposed to CSR, not through campaigns targeted at consumers, but rather through exposure to CSR initiatives in the workplace. This hypothesis supports Christiansen's (1997) finding that much CSR communication is effectively an act of auto-communication; that is, the audience most affected is that within the organization itself rather than its external communities. Studies of other countries have found a difference between employees working in the public versus the private sector in terms of levels of ethical awareness and response to CSR, for example, Mujtaba et al.'s (2011) for Iran and Lyons et al.'s (2006) for Canada. However, our study revealed no significant differences related to employment in the public versus the private sector. The fact that a wide range of both public and private sector organizations in the

Table 3 Results of Levene's test for equality of variances relating to gender

\begin{tabular}{|c|c|c|c|c|c|c|c|c|c|}
\hline & \multirow[t]{3}{*}{$\mathrm{F}$} & \multirow[t]{3}{*}{ Sig. } & \multicolumn{7}{|c|}{$t$ test for equality of means } \\
\hline & & & \multirow[t]{2}{*}{$t$} & \multirow[t]{2}{*}{$\mathrm{df}$} & \multirow[t]{2}{*}{ Sig. (2-tailed) } & \multirow[t]{2}{*}{$\begin{array}{l}\text { Mean } \\
\text { difference }\end{array}$} & \multirow[t]{2}{*}{$\begin{array}{l}\text { Std. error } \\
\text { difference }\end{array}$} & \multicolumn{2}{|c|}{$\begin{array}{l}95 \% \text { confidence interval of the } \\
\text { difference }\end{array}$} \\
\hline & & & & & & & & Lower & Upper \\
\hline \multicolumn{10}{|l|}{ Awareness of CSR } \\
\hline Equal variances assumed & .624 & .430 & -.414 & 260 & 679 & -.028 & .067 & -.159 & .104 \\
\hline Equal variances not assumed & & & -.410 & 120.283 & .683 & -.028 & .068 & -.161 & .106 \\
\hline
\end{tabular}


Table 5 Familiarity with term correlated with educational level

\begin{tabular}{|c|c|c|c|c|c|c|}
\hline \multicolumn{7}{|l|}{ Tukey HSD } \\
\hline \multirow[t]{2}{*}{ (I) Educational levels } & \multirow[t]{2}{*}{$(J)$ Educational levels } & \multirow[t]{2}{*}{ Mean difference $(I-J)$} & \multirow[t]{2}{*}{ Std. error } & \multirow[t]{2}{*}{ Sig. } & \multicolumn{2}{|c|}{$95 \%$ confidence interval } \\
\hline & & & & & Lower bound & Upper bound \\
\hline \multirow[t]{2}{*}{ Primary } & High School & .130 & .144 & .637 & -.21 & .47 \\
\hline & University & $.423^{\mathrm{a}}$ & .131 & .004 & .11 & .73 \\
\hline \multirow[t]{2}{*}{ High School } & Primary & -.130 & .144 & 637 & -.47 & .21 \\
\hline & University & $.292^{\mathrm{a}}$ & .075 & .000 & .11 & .47 \\
\hline \multirow[t]{2}{*}{ University } & Primary & $-.423^{\mathrm{a}}$ & .131 & .004 & -.73 & -.11 \\
\hline & High School & $-.292^{\mathrm{a}}$ & .075 & .000 & -.47 & -.11 \\
\hline
\end{tabular}

${ }^{a}$ The mean difference is significant at the 0.05 level

Table 6 Familiarity with term correlated with employment status

\begin{tabular}{|c|c|c|c|c|c|c|c|c|}
\hline \multirow[t]{2}{*}{ 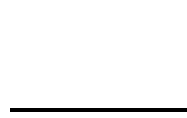 } & \multirow[t]{2}{*}{$N$} & \multirow[t]{2}{*}{ Mean } & \multirow[t]{2}{*}{ Std. deviation } & \multirow[t]{2}{*}{ Std. error } & \multicolumn{2}{|c|}{$95 \%$ confidence interval for mean } & \multirow[t]{2}{*}{ Minimum } & \multirow[t]{2}{*}{ Maximum } \\
\hline & & & & & Lower bound & Upper bound & & \\
\hline Student & 126 & 1.67 & .473 & .042 & 1.58 & 1.75 & 1 & 2 \\
\hline Not working & 41 & 1.83 & .381 & .059 & 1.71 & 1.95 & 1 & 2 \\
\hline Government & 58 & 1.57 & .500 & .066 & 1.44 & 1.70 & 1 & 2 \\
\hline Private sector & 31 & 1.52 & .508 & .091 & 1.33 & 1.70 & 1 & 2 \\
\hline Total & 256 & 1.65 & .477 & .030 & 1.59 & 1.71 & 1 & 2 \\
\hline
\end{tabular}

Table 7 Familiarity with term correlated with employment status

\begin{tabular}{lrlc}
\hline Tukey HSD & & \\
\hline Employment & $N$ & \multicolumn{2}{l}{ Subset for $\alpha=0.05$} \\
\cline { 3 - 4 } & & 1 & 2 \\
\hline Private sector & 31 & 1.52 & \\
Government & 58 & 1.57 & 1.67 \\
Student & 126 & 1.67 & .321 \\
Not working & 41 & & .391 \\
Sig. & & .39
\end{tabular}

Means for groups in homogeneous subsets are displayed

${ }^{\mathrm{a}}$ Uses harmonic mean sample size $=48.884$

b The group sizes are unequal. The harmonic mean of the group sizes is used. Type I error levels are not guaranteed

UAE engage in various types of CSR activities may account for our finding.

\section{CSR Orientations}

Question 2 asked respondents to provide their own explanation of CSR and we then identified the themes that emerged from their definitions. Responses were easily classified under three categories: social development$51.7 \%$; environmental protection-20.4\%; and charity$19.1 \%$. A further $5.9 \%$ defined it as both a constituent of environmental protection and social development, and $2.9 \%$ defined it as having a role in both social development and charity. We can interpret the explanations focusing on social development and environmental protection as including the social and environmental dimensions of Dahlsrud's (2008) analysis of how CSR is defined. If we refer to Carroll's (1991) work on the pyramid of different priorities in CSR campaigns and Visser's (2007) re-working of this for emerging economies, these findings indicate that almost three quarters of our respondents $(72.1 \%)$ interpret CSR in ethical rather than philanthropic terms. In contrast, only $22 \%$ (that is, $19.1+2.9 \%$ ) of them made a specific link with philanthropic CSR. This runs counter to what Visser (2007) identified as a priority for consumers in the developing world and it is similar to the finding of Lindgreen et al. (2009) for managers in Botswana and Malawi. The significant number of respondents who identified CSR as environmental protection somewhat echoes the findings of Yakovleva and Vazquez-Brust (2012) for CSR within the mining sector in Argentina where environmental issues are considered paramount.

\section{Belief in CSR as an Economic Driver}

The exponential growth of Dubai over recent decades renders the issue of the country's social and post-oil economic 
development prominent for many Emiratis. Question 3 queried respondents' views on the role that CSR can play in the development of their economy. A substantial number of respondents, $72.8 \%$, expressed the belief that it can contribute and this could be regarded as indicating an awareness of CSR as an integral part of wealth creation rather than as just an added-on philanthropic component. This equates to the economic dimension of Dahlsrud's (2008) definition of CSR and Carroll's $(1979,1991)$ economic orientation. We pursued this line by querying respondents further as to the particular ways in which they believed CSR contributes. Close to half (40\%) stated that it provides economic benefits to the community at large which can once again be interpreted as ethical CSR, that is, they perceived economic contribution associated with CSR as a norm-imposed obligation or something which is viewed as contributing to the common good. In contrast, only $8.9 \%$ stated that its economic benefit is in the form of charity indicating these respondents' equation of CSR with philanthropy rather than with ethical CSR. Yakovleva and Vazquez-Brust (2012, p. 194) make the point that "CSR in developing countries is less formalized and institutionalized; business often deals with social issues that in developed countries are mostly government responsibility, such as investment in infrastructure, schools, hospitals and housing." In contrast, in the case of Dubai, its strong economy has allowed its government to successfully provide this infrastructure and this would also encourage locals to perceive CSR less in philanthropic terms. That is, given that their basic needs have already been met they have no need of philanthropy and are therefore in a position to envision CSR as a means to achieving more advanced environmental and economic objectives.

A further $17.8 \%$ of respondents identified a benefit of CSR as that of spreading awareness of particular issues. This perhaps suggests some confusion between purely informative campaigns for social good, such as governmental health and safe driving campaigns, and corporate initiatives used as part of social marketing campaigns. Increased sales and company revenue were cited by $11.1 \%$ as a benefit of CSR. This is quite a low figure and suggests that our respondents were focused more on the broader social and environmental benefits of CSR than on the specific economic advantage to be accrued by individual organizations engaging in CSR. These interpretations of CSR contrast starkly with both the findings of a study in Cyprus, where most respondents believed the main reason for engagement in CSR was because of the fiscal benefits to the organization resulting from tax-deductible CSR expenditure (Papasolomou-Doukakis et al. 2005), as well as the widely held belief reported in India that at least some corporations engage in philanthropic CSR as a means to hide corruption (Sundaresan 2010). Our Dubai respondents display a more positive attitude to CSR.
Religious Dimension of CSR and zakat

Given the dominance of the practice of almsgiving within the local culture of Dubai, we wished to investigate if this Islamic precept would have a significant impact on the Emirati conceptualization of the nature and role of CSR. Existing studies have indeed indicated that it does. Qasim et al. (2011), for example, argue that much CSR conducted in the UAE is, in Carroll's (1991) terms, more philanthropic than ethical, and Rettab et al. (2009) insist that many companies operating in the UAE design their CSR initiatives as philanthropy in line with the principles of zakat. Our fourth question probed the possible influence of zakat on how CSR is perceived and, significantly, 59.8\% stated that there is no relationship between CSR and zakat. This distinction between a religious precept and CSR reflects the view expressed by Western consumers in previous studies that the emphasis should be on an ethical orientation and discretionary philanthropy and not on CSR as an obligatory philanthropic initiative.

The distinction made by our respondents between CSR and zakat may be due partly to the recent increase in high profile ethical CSR initiatives specifically related to the environment and the general emphasis on environmental issues in the UAE. One example of such an initiative is the UAE government's undertaking to reduce the country's carbon footprint (http://www.footprintnetwork.org/images/ uploads/UAE_LPR_supplement_EN.pdf). Another is the experimental city, Masdar, vaunted to be the world's first carbon free community and located on the outskirts of Abu Dhabi, the UAE capital (http://www.masdar.ae). Such widely publicized initiatives perhaps made it possible for our respondents to distinguish CSR, as a sustainable social or ethical obligation, from traditional forms of zakat that are more similar to philanthropy. This provides an example of Quazi's (2003) concept of CSR as representing a changing social contract determined by a general agreement between business and society since our finding suggests there is a shifting view toward a concern with environmental issues. We could hypothesize that given Dubai's meteoric rise as a commercial hub with the concomitant strong presence of MNCs there and the currently high levels of education among its citizens, the local population has quickly absorbed a more evolved form of CSR and is able to distinguish CSR activities from the Islamic tradition of personal and corporate donations.

\section{Implications for Managers and Policy Makers}

The low levels of general familiarity with CSR and the almost negligible knowledge of specific CSR initiatives among our Emirati respondents suggest that CSR is a largely 
untapped resource for organizations operating in Dubai. Moreover, our findings in relation to the perception of CSR versus zakat are at variance with current views on implementing CSR in Muslim contexts. That is, scholars such as Saeed et al. (2001) assert that Muslim countries tend to focus on those values that derive directly from their religion and Katsioloudes and Brodtkorb (2007, p. 12) assert that "the heavy influence of Islam on businesses in the [Gulf] region implies a strong foundation upon which to establish CSR policies and practices" (2007, p. 12). However, almost $60 \%$ of our respondents did not perceive a link between CSR and Islamic philanthropy (question 4) indicating that respondents did not typically associate CSR with religious principles. In Kohlberg's (1969) terms, we could interpret this as a shift from the stage of maintaining social order-as would be the case if the new practice of CSR is regarded as fitting the mold of traditional zakat - to a stage of universal principles in which individuals work toward a conception of a good society - the CSR principle of promoting ethically mature corporate and social citizenship.

The managerial implication of our findings is that consumers within the increasingly sophisticated economic context of Dubai appear ready to embrace CSR as a force for social and economic development. Dahlsrud (2008, p. 6) argues "the challenge for business is not so much to define CSR, as it is to understand how CSR is socially constructed in a specific context and how to take this into account when business strategies are developed." Our study suggests that managers need to be more conscious of the impact of high wealth indicators on culture as they attempt to roll out CSR initiatives in emerging economies. Indeed, indications that the principle of helping less privileged members of society is already evolving, is suggested by the increase in volunteerism. One example of this is the highly successful "Dubai Cares" campaign. This initiative began in 2007 during Ramadan, a month of fasting and repentance and the most active time for almsgiving, when it set out to collect money to fund primary school education in developing countries. By the following year, it had shifted focus from the straightforward collection of money to the encouragement of citizens to devote their time to initiatives aimed at social improvement both within and outside the country's boundaries (Al Lawati 2008). We could construe this as an evolution of the original donation of money to the poor toward a more sophisticated, and sustainable, interpretation of social assistance. An analogous development that may be noted here is the awareness on the part of some Muslim scholars of the need to revisit zakat to render it more relevant to modern systems of taxation, fiscal control, and social commitment (Hasan and Al Jaouhair 2010).

This apparent evolution of philanthropy has not yet emerged from studies on the conceptualization of CSR in other Muslim countries. For example, in the largely Mus$\lim$ Arab countries of Lebanon, Jordan, and Syria, CSR is still understood and practiced as philanthropic action (Jamali and Mirshak 2007; Jamali et al. 2008; Jamali and Sidani 2012) and in Muslim Turkey the drivers associated with CSR are identified as being institutional and exogenous rather than cultural or endogenous (Ararat 2008). The difference may be a result of the economic health of a country. The UAE has a per capita GDP of USD 42,691, Lebanon, USD 9,764, Syria, USD5100 (estimated), and Turkey, USD 10,946 (World Bank 2013). The implication is that policy makers need to balance their concern with local culture and religion with the economic variables of a country rather than approaching CSR design solely from the perspective of culture and religion.

What makes our Dubai study significant is the lack of local need for corporate contribution to infrastructure, education, healthcare, and housing that characterizes the expectations of CSR within low GDP countries. Our findings suggest that local consumers in Dubai have gone beyond an equation of CSR and philanthropy which indicates that organizations may no longer need to confine themselves to developing their CSR activities on philanthropic lines as suggested in earlier studies (Rettab et al. 2009; Qasim et al. 2011).

\section{Limitations and Future Research Directions}

Given the dearth of research on consumer attitudes to CSR in Dubai, we restricted our study to a preliminary exploration of this and did not assess managerial perspectives or consumer loyalty in relation to CSR initiatives. Yet, despite its limitations, we believe our investigation offers an important contribution by highlighting the fact that Dubai consumers seem prepared to embrace CSR initiatives that go beyond philanthropy and that feed into social, environmental, and economic amelioration. This point has significant implications for Dubai-based businesses wishing to enhance their CSR platforms, suggesting the potential value of ethical CSR campaigns that refer to, but are not limited to, the Islamic precept of concern for one's community. Such a strategy may usefully guide the implementation of a Triple Bottom Line approach which can satisfy both religious and cultural values and the increasingly sophisticated understanding of the role of CSR in Dubai's fast changing social and economic climate.

The evolving conceptualization of CSR in the fast changing countries of the Arabian Gulf is a fertile research area. This is so partly because, while they represent emerging economies with a strong religious tradition of philanthropy, their governments have been able to provide the infrastructures often contributed by corporate philanthropy in developing nations. They can, therefore, 
be expected to represent a different approach to CSR from that typical of the low GDP emerging nations that have been investigated by scholars. An exploration of this evolving conceptualization would not only ensure greater satisfaction for the increasingly sophisticated, educated, and wealthy Muslim population worldwide, but it would also feed more effectively into social and environmental improvement within each local context. In Dahlsrud's (2008) terms, corporations and scholars need to consider how, in economically robust Muslim countries, economic orientations identified by our respondents could be incorporated into CSR in parallel with Islamic principles of philanthropy.

Open Access This article is distributed under the terms of the Creative Commons Attribution License which permits any use, distribution, and reproduction in any medium, provided the original author(s) and the source are credited.

\section{References}

Al Lawati, A. (2008). "Dubai Cares" campaign shifts focus to volunteerism in second phase. Gulf News. July 8, 2008. Retrieved December 23, 2011, from http://gulfnews.com/news/gulf/uae/ government/dubai-cares-campaign-shifts-focus-to-volunteerism-insecond-phase-1.117229.

Ararat, M. (2008). A development perspective for "corporate social responsibility": Case of Turkey. Corporate Governance, 8(3), 271-285.

Arevalo, J. A., \& Aravind, D. (2011). Corporate social responsibility practices in India: Approach, drivers, and barriers. Corporate Governance, 11(4), 399-414.

Arora, B., \& Puranik, R. (2004). A review of corporate social responsibility in India. Development, 47(3), 93-100.

Arslan, M. (2001). The work ethic values of Protestant British, Catholic Irish and Muslim Turkish managers. Journal of Business Ethics, 31(4), 321-339.

Bhattacharya, C. B., \& Sen, S. (2004). Doing better at doing good: When, why, and how consumers respond to corporate social initiatives. California Management Review, 47(1), 9-24.

Block, N. (1995). On a confusion about a function of consciousness. Behavioral and Brain Sciences, 18(2), 227-287.

Brammer, S., Williams, G., \& Zinkin, J. (2007). Religion and attitudes to corporate social responsibility in a large crosscountry sample. Journal of Business Ethics, 71(3), 229-243.

Brislin, R. W. (1980). Translation and content analysis of oral and written materials. In H. C. Triandis \& J. W. Berry (Eds.), Handbook of cross-cultural psychology (Vol. 2, pp. 137-164)., Methodology Boston, MA: Allyn and Bacon.

Carroll, A. (1979). A three-dimensional conceptual model of corporate performance. Academy of Management Review, 4(4), 497-505.

Carroll, A. B. (1991). The pyramid of corporate social responsibility: Toward the moral management of organizational stakeholders. Business Horizons, 34, 39-48.

Chapple, W., \& Moon, J. (2005). Corporate social responsibility in Asia: A seven-country study of CSR web site reporting. Business and Society, 44(4), 415-441.

Christensen, L. T. (1997). Marketing as auto-communication. Consumption, Markets and Culture, 3, 197-227.
Cornwell, B., Cui, C. C., Mitchell, V., Schlegelmilch, B., Dzulkiflee, A., \& Chan, J. (2005). A cross-cultural study of the role of religion. International Marketing Review, 22(5), 531-546.

Dahlsrud, A. (2008). How corporate social responsibility is defined: An analysis of 37 definitions. Corporate Social Responsibility and Environmental Management, 15(1), 1-13.

Dalton, D., \& Ortegren, M. (2011). Gender differences in ethics research: The importance of controlling for the social desirability response bias. Journal of Business Ethics, 20(1), 1-21.

Du, S., Bhattacharya, C. B., \& Sen, S. (2010). Maximising business returns to corporate social responsibility (CSR): The role of CSR communication. International Journal of Management Reviews, 12(1), 8-19.

Dubai Statistics Centre. (2011). Population bulletin: Emirate of Dubai. Retrieved December 23, 2014, from http://www.dsc.gov. ae/Publication/Pop\%20Eng1\%202010.pdf.

Epps, A., \& Demangeot, C. (2013). The rainbow of diversity versus the rain of fragmentation. Foresight: The Journal of Futures Studies, Strategic Thinking and Policy, 15(4), 307-320.

Esrock, S., \& Leichty, G. (1998). Social responsibility and corporate web pages: Self-presentation or agenda setting? Public Relations Review, 24(3), 305-319.

Goby, V. P. (2009). Primacy of personal over cultural attributes: Demonstrating receptiveness as a key to effective cross-national interactions. Canadian Social Science, 5, 91-104.

Goby, V. P., \& Nickerson, C. (2012). Introducing ethics and corporate social responsibility at undergraduate level in the United Arab Emirates: An experiential exercise on website communication. Journal of Business Ethics, 107(2), 103-109.

Graafland, J., Kaptein, M., \& Mazereeuw, C. (2006a). Business dilemmas and religious belief: An explorative study among Dutch executives. Journal of Business Ethics, 66(1), 53-70.

Graafland, J., Mazereeuw, C., \& Yahia, A. (2006b). Islam and socially responsible business conduct: An empirical study of Dutch entrepreneurs. Business Ethics: A European Review, 15(4), 390-406.

Hasan, S. \& Al Jaouhair, A. (2010). Muslim philanthropy and human development: Replicable lessons from the Gulf. In: Proceedings of the Conference of the International Society for Third-Sector Research (Istanbul, Turkey, 7-10 July). http://istr.conferenceservices.net/resources/588/1799/pdf/ISTR2010_0239.pdf.

Hastings-Black, M. (2011). The overlooked \$170 billion of MuslimAmerican spending power. Huffington Post, 30 November 2011. http://www.huffingtonpost.com/michael-hastingsblack/the-over looked-170-billio_b_162018.hml.

Jamali, D. (2010). The CSR of MNC subsidiaries in developing countries: Global, local, substantive or diluted. Journal of Business Ethics, 93, 181-200.

Jamali, D., \& Mirshak, R. (2007). Corporate social responsibility (CSR): Theory and practice in a developing country context. Journal of Business Ethics, 72(3), 243-262.

Jamali, D., \& Sidani, Y. (2012). CSR in the Middle East: Fresh perspectives. London: Palgrave Publishers.

Jamali, D., \& Sidani, Y. (2013). Does religiosity determine affinities to CSR? Journal of Management, Spirituality and Religion, 10(4), 309-323.

Jamali, D., Sidani, Y., \& El-Asmar, K. (2009a). A three country comparative analysis of managerial CSR perspectives: Insights from Lebanon, Syria and Jordan. Journal of Business Ethics, 85, 173-192.

Jamali, D., Zanhour, M., \& Keshishian, T. (2009b). Peculiar strengths and relational attributes of SMEs in the context of CSR. Journal of Business Ethics, 87, 355-377.

Katsioloudes, M. I., \& Brodtkorb, T. (2007). Corporate social responsibility: An exploratory study in the United Arab Emirates. S.A.M. Advanced Management Journal, 72(4), 9-20.

Kennedy, E. J., \& Lawton, L. (1998). Religiousness and business ethics. Journal of Business Ethics, 17(2), 163-175. 
Kohlberg, L. (1969). Stage and sequence: The cognitive-developmental approach to socialization. In D. Grosling (Ed.), Handbook of socialization theory and research (pp. 347-480). Chicago: Rand McNally.

Lindgreen, A., Cordoba, J. R., Maon, R., \& Mendoza, J. M. (2010). Corporate social responsibility in Colombia: Making sense of social strategies. Journal of Business Ethics, 91, 229-242.

Lindgreen, A., Swaen, V., \& Campbell, T. T. (2009). Corporate social responsibility practices in developing and transnational countries: Botswana and Malawi. Journal of Business Ethics, 90, $429-440$.

Lyons, S. T., Duxbury, L. E., \& Higgins, C. A. (2006). A comparison of the values and commitment of private sector, public sector, and parapublic sector employees. Public Administration Review, 66(4), 605-618.

Maignan, I., \& Ralston, D. (2002). Corporate social responsibility in Europe and the US: Insights from businesses self-presentations. Journal of International Business Studies, 33, 497-514.

Majaj, Y., \& Kassis, S. (2012). CSR and philanthropy: Different forms of effective social investment. In D. Jamali \& Y. Sidani (Eds.), CSR in the Middle East: Fresh perspectives (pp. 11-24). London: Palgrave Publishers.

Marty, M. E., \& Appleby, R. S. (1993). Fundamentalisms and the state: Remaking polities, economies, and militance. Chicago: University of Chicago Press.

Mujtaba, B. G., Tajaddini, R., \& Chen, L. Y. (2011). Perceptions of ethics by public and private sector Iranians. Asian Journal of Business and Management Sciences, 1(2), 104-118.

Muruganantham, G. (2010). Case study on corporate social responsibility in MNC's in India. Paper presented at the International Trade and Academic Research Conference (ITARC), 8-10 November 2010, London, UK.

Muthuri, J. N., Chapple, W., \& Moon, J. (2009). An integrated approach to implementing "community participation" in corporate community involvement: Lessons from Magadi Soda Company in Kenya. Journal of Business Ethics, 85, 431-444.

Nickerson, C., \& Crawford-Camiciottoli, B. (2013). Business English as a lingua franca in advertising texts in the Arabian Gulf: Analyzing the attitudes of the Emirati Community. Journal of Business and Technical Communication, 27(3), 329-352.

Oumlil, A. B., \& Balloun, J. L. (2009). Ethical decision-making differences between American and Moroccan managers. Journal of Business Ethics, 84(4), 457-478.

Papasolomou-Doukakis, I., Krambia-Kapardis, M., \& Katsioloudes, M. (2005). Corporate social responsibility: The way forward? Maybe not! A preliminary study in Cyprus. European Business Review, 17(3), 263-279.

Planken, B., Nickerson, C., \& Sahu, S. (2013). Corporate Social Responsibility (CSR) across the globe: Dutch and Indian consumers' responses to CSR. International Journal of Organizational Analysis, 21(3), 357-372.

Podnar, K., \& Golob, U. (2007). CSR expectations: The focus of corporate marketing. Corporate Communications: An International Journal, 12(4), 326-340.

Qasim, Z., Muralidharan, P., \& Ramaswamy, G. (2011). Corporate social responsibility and impact of CSR practices in the United Arab Emirates. In: Proceedings of the International Conference on Technology and Business Management, Dubai, March 28-30, 2011, pp. 109-120. http://www.trikal.org/ictbm11/pdf/csr/D1179done.pdf.

Quazi, A. (2003). Identifying the determinants of corporate managers' perceived social obligations. Management Decision, 41(9), 822-831.

Quazi, A., \& O'Brien, D. (2000). An empirical test of a cross-national model of corporate social responsibility. Journal of Business Ethics, 25, 33-51.
Ramasamy, B., \& Ting, H. W. (2004). A comparative analysis of corporate social responsibility awareness. Journal of Corporate Citizenship, 13(13), 109-123.

Ramasamy, B., Yeung, M. C., \& Au, A. K. (2010). Consumer support for corporate social responsibility (CSR): The role of religion and values. Journal of Business Ethics, 91(1), 61-72.

Randall, M., \& Samimi, M. (2010). The status of English in Dubai: A transition from Arabic to English as a lingua franca. English Today, 26, 43-50.

Rettab, B., Brik, A. B., \& Mellahi, K. (2009). A study of management perceptions of the impact of corporate social responsibility on organizational performance in emerging economies: The case of Dubai. Journal of Business Ethics, 89, 371-390.

Rice, G. (1999). Islamic ethics and the implications for business. Journal of Business Ethics, 18(4), 345-358.

Rice, G., \& Al-Mossawi, M. (2002). The implications of Islam for advertising messages: The Middle Eastern context. Journal of Euromarketing, 11(3), 71-96.

Ringov, D., \& Zollo, M. (2007). The impact of national culture on corporate social performance. Corporate Governance, 7(4), 476-485.

Robertson, D. C. (2009). Corporate social responsibility and different stages of economic development: Singapore, Turkey, and Ethiopia. Journal of Business Ethics, 88(4), 617-633.

Robertson, D. C., \& Ross, T. W, Jr. (2003). A typology of situational factors: Impact on salesperson decision-making about ethical issues. Journal of Business Ethics, 46, 213-234.

Saeed, M., Ahmed, Z. U., \& Mukhtar, S. M. (2001). International marketing ethics from an Islamic perspective: A value-maximation approach. Journal of Business Ethics, 32(2), 127-142.

Sagar, P., \& Singla, A. (2004). Trust and corporate social responsibility: Lessons from India. Journal of Communication Management, 8(3), 282-290.

Salem, O., \& Dajani, H. (2013). FNC would like Emiratisation to become law. The National, 19 November 2013. http://www. thenational.ae/uae/government/fnc-would-like-emiratisation-tobecome-law.

Schmitt, N. W., \& Stutts, D. M. (1985). Factors defined by negatively keyed items: The results of careless respondents? Applied Psychological Measurement, 9(4), 367-373.

Schneider, H., Krieger, J., \& Bayraktar, A. (2011). The impact of intrinsic religiosity on consumers' ethical beliefs: Does it depend on the type of religion? A comparison of Christian and Moslem consumers in Germany and Turkey. Journal of Business Ethics, 102(2), 319-332.

Sen, S., Bhattacharya, C. B., \& Korschun, D. (2006). The role of corporate social responsibility in strengthening multiple stakeholder relationships: A field experiment. Journal of the Academy of Marketing Science, 34(2), 158-166.

St. Amant, K. (2002). When cultures and computers collide. Rethinking computer-mediated communication according to international and intercultural communication expectations. Journal of Business and Technical Communication, 16(2), 196-214.

Sundaresan, S. (2010). Govt's approach to CSR gives scope for corruption. Business Standard, 13 September 2010. http://www. business-standard.com/india/news/govt $\% 5$ Cs-approach-to-csrgives-scope-for-corruption/407860/.

Swimberghe, K., Flurry, L. A., \& Parker, J. M. (2011). Consumer religiosity: Consequences for consumer activism in the United States. Journal of Business Ethics, 103(3), 453-467.

Tian, Z., Wang, R., \& Yang, W. (2011). Consumer responses to corporate social responsibility (CSR) in China. Journal of Business Ethics, 101, 197-212.

Turker, D. (2009a). How corporate social responsibility influences organizational commitment. Journal of Business Ethics, 89, 189-204. 
Turker, D. (2009b). Measuring corporate social responsibility: A scale development study. Journal of Business Ethics, 85, 411-427.

Visser, W. (2007). Revisiting Carroll's CSR pyramid: An African perspective. In A. Crane \& D. Matten (Eds.), Corporate social responsibility: Three volume set (pp. 195-212). London: Sage.

Vitell, S. J., Paolillo, J. G. P., \& Singh, J. J. (2005). Religiosity and consumer ethics. Journal of Business Ethics, 57(2), 175-181.

Vitell, S. J., Paolillo, J. G. P., \& Singh, J. J. (2006). The role of money and religiosity in determining consumers' ethical beliefs. Journal of Business Ethics, 64(2), 117-124.

Weiss, C. E. (1998). Negotiating with foreign business persons: An introduction for Americans with propositions on six cultures. In S. Niemeier, C. P. Campbell, \& R. Dirven (Eds.), The cultural context in business communication (pp. 51-118). Philadelphia: Benjamin.
World Bank. (2013). GDP per capita (current US\$). Retrieved September 9, 2014, from http://data.worldbank.org/indicator/ NY.GDP.PCAP.CD.

World Economic Outlook Database-September. (2011). Retrieved January 29, 2012, from http://www.imf.org.

Yakovleva, N., \& Vazquez-Brust, D. (2012). Stakeholder perspectives on CSR of mining MNCs in Argentina. Journal of Business Ethics, 106, 191-211.

Zakaria, N., Stanton, J. M., \& Sarkar-Barney, S. T. M. (2003). Designing and implementing culturally-sensitive IT applications: The interaction of culture, values, and privacy issues in the Middle East. Information Technology and People, 16(1), 49-75. 